\title{
EVALUATION OF SPECIAL COMPONENTS OF SOME PLANT OILS IN VARROA DESTRUCTOR CONTROL
}

\author{
H.T. Abou Elenain ${ }^{(1)}$, Asmaa A. Eisa ${ }^{(1)}$, Naglaa E. Ghazala(1) \\ and Suzan Ibrahim ${ }^{(2)}$ \\ (1) Honeybee Research Department, Plant Protection Research Institute ,Agriculture Research \\ Centre, Dokki Giza. \\ (2) Faculty of Pharmacy, Tanta University.
}

Received: Jul. 2, 2016

Accepted: Aug. 13, 2016

\begin{abstract}
This work was conducted in the Experimental Apiary of Plant Protection Institute at Gemmiza Research Station, Gharbia governorate and in laboratory of Faculty of Pharmacy, Tanta University to evaluate the effect of some essential components from natural substances : Clove oil (Eugenol), Menthol oil (Menthone) and Camphor oil (Cineol) in Varroa destructor control in honeybee colonies through the period of 1/11 to 28/11/2014 and 1/12 to 28/12/2015. Results revealed that, the mean reduction of infection with Varroa mite could be arranged into the following descending orders as follows: $71.20 \%, 64.00 \%, 68.55 \%$ for Clove oil, Menthol oil and Camphor oil. In case of infestation of honeybee colonies with varroa mites, it is advisable to use the derived compounds : Eugenol, Menthone and Cineol especially at Winter season after honey harvesting.
\end{abstract}

Key words: Honeybee, Varroa mites, Clove oil. , Camphor oil, Menthol oil.

\section{INTRODUCTION}

Varroa jacobsoni Oud. (Acarina: Varroidae), is the most serious parasite of honey bees, Apis mellifera (Hymenoptera: Apidae) in the USA. Varroa destructor has become the most dangerous pest of honeybee colonies in Egypt. this mite was recorded for the first time in Egypt in 1983 Wienands and Madel,(1988). Migratory beekeeping, importation of colonies packages of bees and queens, are considered to bee the possible ways of varroa spread. The spread of varroa within colonies is due to swarming, robbing and foraging. Varroa disease resulted in weakened bee colonies malformations in wings and abdomen Dehibes et al. (1992). In the past years, the primary chemical has been used to control varroa was the pyrethroid flavalinate, followed by the organo phosphours and then by formic acid. Each compound has negative associated with their use. It is impact has been compounded because these Varroa mite quickly became resistant and reduction of their efficacy Milani(1999). The remaining of the chemicals adverse effects on environment, Wallner(1995), and lead contamination of colony products, Wallner(1999).the use of natural products for controlling parasitic bee mites are safe, Jacobson(1983), Emara and Elsisi (1994), Colin(1990), Lui and Nasr(1993), Kraus and Berg(1994), Calderone and Spivak(1995), Xie et al.(1995), Calderone et al. (1997) and Hagigatian(2000). Cupric organic salts therefore provide a safe way for preventing the infestation of colonies and the population development of the mite over long periods. Bounias et al. (1994). Populations of Varroa jacobsoni in honeybee colonies showed seasonal high densities in the spring and autumn. Numbers of maternal mites and/or their progeny in drone cells were higher than in worker cells. Food suitability and amount of resources, e.g., food and space, were higher in drone cells than in worker cells. The fact that mites concentrated on the "brood nests" located in the mid-low portion of the comb was consistent with the egglaying pattern of the queen, Chen and Shih (1995). The varroa mite, Varroa immatures and adults feed on bee haemolymph, causing morphological abnormalities and transmitting debilitating viruses. Without 
control efforts by man, varroa eventually destroy the colony within ca. 2 years. Application of smoke from burning of grapefruit leaves over varroa-infested honey bees has been shown to cause biological activity on the varroa: Elzen et al. (2001). Different dosages, ways and times of application have been tested on colonies in the post, often reporting highly satisfactory results (range of mean effectiveness 6699.5\%) Imdrof et al. (1999). The application of some plant extracts or essential oils based on products against infested apiaries were found to maintain mite infestation rates economic, Calderone et al. (1997) and Hagigatian (2000). The mean reduction of infestation when using natural compound as tablet against Varroa mite could be arranged in descending order as follows: clove, marjoram and ginger. Using natural compounds as capsules, the marjoram and clove caused reduction of infestation reached $86.6 \%$ Abou El-Enain et al. ( 2005). An important repellant effect was observed with neem extracts, which interfered with the ability of female varroa to locate bee pupae to feed on. The neem-based products had a persistent repellency effect that lasted approximately $48 \mathrm{~h}$ Gonzalez-Gomez et al. (2006) . Several plant extracts especially neliaceous species such as the highly reputed neem tree were evaluated, ShaddelTelli et al. (2008). In addition , Azadirachta indica and certain members of the genus Swietenia, were successfully control varroa mites, Mikolojczak and Reed (1987) ,Jimenez et al. (1997), Omar et al. (2007). The mean reduction of infection with Varroa mite could be arranged in descending order as : $89.49 \%, 89.49 \%, 77.87 \%$ (in brood and on adult) using plates Apiguard, Clove and Camphor, respectively ( Abou El-Enain et al., 2014).
From the previous results, the present work aimed to study the effect of essential component from natural substances on Varroa destructor control in honeybee colonies.

\section{MATERIAL AND METHODS}

This experiment was carried out under the apiary conditions in Gemmiza research station, Gharbia governorate, and in laboratory of Faculty of Pharmacy, Tanta University to study the effect of major components in some oils (Clove, Menthol and Camphor) during the period of $1 / 11$ to $28 / 11 / 2014$ and of $1 / 12$ to 28/12/2015 against Varroa destructor in honeybee colonies.

\section{Honey bee strains and numbers:}

Twelve honey bee Carniolan were selected where the strength colony contains at least seven frames covering with bees, and headed with equal queen ages. The colonies have been divided into 4 groups (each of 3 colonies), colonies in each group were insignificant of infested with Varroa mite in adult.

Clove and Camphor oils were obtained from El Gomhoria company while Menthol oil was obtained from $\mathrm{El} N a s r$ pharmaceutical company Abu Zabal.

This work was done at the laboratory of faculty of pharmacy, Tanta university. Clove, Menthol and Camphor oils were subjected to obtain the active substance (Ismail,1953) .

\section{HPLC method analysis:}

Column: Hypersil BDS-C18 5 micrm m $4.6^{*} 150 \mathrm{~mm}$

Mobil phase: Water / methanol.

\begin{tabular}{|c|c|c|c|}
\hline Time (minute) & Methanol & Water & Flow \\
\hline 0 & 10 & 90 & $0.7 \mathrm{ml} / \mathrm{min}$ \\
\hline 3 & 20 & 80 & $0.7 \mathrm{ml} / \mathrm{min}$ \\
\hline 5 & 30 & 70 & $0.7 \mathrm{ml} / \mathrm{min}$ \\
\hline 10 & 50 & 50 & $0.7 \mathrm{ml} / \mathrm{min}$ \\
\hline 20 & 70 & 30 & $0.7 \mathrm{ml} / \mathrm{min}$ \\
\hline 30 & 100 & 0 & $0.7 \mathrm{ml} / \mathrm{min}$ \\
\hline
\end{tabular}

Flow rate: $0.7 \mathrm{ml} / \mathrm{min} \quad$ Inj vol: 0.4 micro I Dedication: $254 \mathrm{~nm} \quad 280 \mathrm{~nm}$ 


\section{Substances used:}

By using HPLC analysis it was found that the major substances were Clove oil (Eugenol), Menthol oil (Menthone) and Camphor oil (Cineol).

\section{Preparing the natural substances:}

These groups were treated according to Ismail (1953) as follows:

Group (A): $0.2 \mathrm{ml}$ (two drops) from Clove oil (Eugenol).

Group (B): $0.2 \mathrm{~g}$ from Menthol oil (Menthone).

Group (C): $0.5 \mathrm{ml}$ (20 drops) from Camphor oil (Cineol).

Group (D): Untreated colonies (Control).

Cineol and Eugenol were put in a piece of cotton while Menthol crystals was put on plastic plate in the hive. The total treatment period was four weeks (from November 2014 and December 2015). The honeybee colonies were fed on sugar syrup (2 sugar : 1 water) one per week The bottom board of the hive was covered with a plastic sheet coated with raw Vaseline to capture the fallen mites. The died Varroa were counted and removed at the end of each treatment.

\section{Determination of Varroa infestation: \\ 1- In brood cells:}

The infestation percentages of Varroa mites in brood cells were determined by randomly examination of 40 worker cells. Reduction percentages in mite infestation was calculated according to the formula of Henderson and Tilton (1955).

\section{2- On workers :}

The percent infestations of Varroa mites on workers before and after treatments were determined according to Komeili (1988). Samples of hundred bees /colony were collected randomly in vial partially filled with water containing few drops of detergent. The samples were shaken and the bees were washed in a strainer, individual mites that fall off from workers bees were found at the bottom of the white container (Ritter,1981). All worker bees and mites were counted for each sample, where the number of mites / 100 workers was calculated .The fallen varroa on the plastic sheet was counted beginning of the treatment till the end.

\section{Statistical analysis:}

The obtained data was statistically analyzed using analysis of variance (ANOVA) at $5 \%$ probability. The measurements were separated using Duncan's Multiple Range Test (DMRT) through CoStat software program (Version 6.400). Copyright (C) 1998-2008 Cohort Software. 798 Lighthouse Ave. PMB 320, Monterey, CA, 93940, USA.

Reduction percentages were counted according to the formula of Henderson and Tilton (1955) :

$\%$ Reduction $=1-\{(\mathrm{Ta} \times \mathrm{Cb}) /(\mathrm{Tb} \times \mathrm{Ca})\} \times$ 100.

Where $\mathrm{T}=$ infestation of treated.

$\mathrm{C}=$ infestation of untreated

$a=$ after treatment.

$\mathrm{b}=$ before treatment.

\section{RESULTS AND DISCUSSION 1-Fallen Varroa mite in honeybee colonies:}

Results in Table (1) show that treating Varroa mites infesting honeybee colonies with the tested material caused significantly higher number of fallen Varroa mites as compared to that of untreated colonies. Mean total of fallen Varroa (286.66 mites) was recorded after using Cineol followed by Eugenol (261.65 mites), Menthol (210.65 mites). The last number of fallen Varroa was recorded in untreated colony (125.95 mites). It can be concluded that, the number of dead fallen mites were increased gradually in case of using natural materials, this might be du to slow action against Varroa mite. 
Evaluation of special components of some plant oils in varroa

Table (1): Mean numbers of fallen Varroa mites after the treatments during November 2014

\begin{tabular}{|c|c|c|c|c|c|c|c|c|c|}
\hline \multirow[t]{2}{*}{ Treatments } & \multicolumn{7}{|c|}{$\begin{array}{l}\text { Mean number of fallen varroa mites after treatment } \\
\qquad \text { (days) }\end{array}$} & \multirow[t]{2}{*}{ Total } & \multirow[t]{2}{*}{ Mean } \\
\hline & 1 & 2 & 3 & 7 & 14 & 21 & 28 & & \\
\hline $\begin{array}{l}\text { Clove oil } \\
\text { (Eugenol) }\end{array}$ & 60.66 & 42.00 & 39.00 & 41.66 & 36.33 & 28.00 & 14.0 & 261.65 & 37.38 \\
\hline $\begin{array}{l}\text { Menthol oil } \\
\text { (Menthone) }\end{array}$ & 26.66 & 34.00 & 32.00 & 34.00 & 46.66 & 17.33 & 20.0 & 210.65 & 30.09 \\
\hline $\begin{array}{l}\text { Camphor oil } \\
\text { (Cineol) }\end{array}$ & 43.00 & 41.33 & 46.00 & 44.00 & 61.00 & 29.33 & 22.0 & 286.66 & 40.95 \\
\hline Untreated & 9.66 & 11.00 & 8.66 & 13.00 & 11.33 & 12.00 & 12.0 & 125.95 & 17.99 \\
\hline
\end{tabular}

The obtained results in Table (2) indicated that the Colve oil caused reduction of infestation being $(60.00)$ and $(82.40 \%)$ for brood cells and adult stage, respectively. The mean reduction of infestation reached $(71.20 \%)$ for both brood and adults. Camphor oil caused reduction of infestation being $(61.70 \%)$ and $(75.40 \%)$ for brood cells and adults, respectively with mean reduction of infestation (68.55\%) for both brood and adults. Menthol oil caused reduction of infestation being $(58.30 \%)$ and $(69.70 \%)$ for brood cells and adults, respectively with mean reduction of infestation (64\%) for both brood and adult stages.

The obtained results in Table (3) cleared that treating Varroa mites infesting honeybee colonies with the tested material caused significantly increase in the number of fallen Varroa mites as compared to that of untreated colonies. Mean total of fallen Varroa was (298.67mites) after using Eugenol followed by Cineol (293.32 mites), while Menthone recorded only (187.32 mites). The least number of fallen Varroa was recorded in untreated colony ( 65.32 mites ).
It can be concluded that, the number of dead fallen mites was increased gradually in case of using natural materials, this might be du to slow action against Varroa mite.

The obtained results in Table (4) indicated that the Clove oil caused reduction of infestation evaluated by (68.20) and $(65.50 \%)$ for brood cells and adults, respectively, with mean reduction of infestation reached $(66.85 \%)$ for both brood and adult . Camphor oil caused reduction of infestation being $(65.90 \%)$ and $(56.80 \%)$ for brood cells and adults, respectively. The mean reduction of infestation reached $(61.35 \%)$ for both brood and adult Menthol oil caused reduction of infestation being $(61.20 \%)$ and $(45.10 \%)$ for brood cells and adult, respectively, The mean reduction of infestation reached $(53.15 \%)$ for both brood and adult stages.

From the obtained results it can be concluded that the application of the compounds extracted from the natural plant oils successfully controlled Varroa mites especially in winter and after the honey harvest .This results coincide with Emara et al. (1994), Imdrof et al. (1995), Mattilla and Otis (2000) and Abou Elenain et al. (2007 , 2014). 
Table (2): Mean reduction percentages of Varroa mites on brood and adult honeybee colonies treated with certain natural substances during November 2014.

\begin{tabular}{|c|c|c|c|c|c|c|c|}
\hline \multirow{2}{*}{ Treatments } & \multicolumn{2}{|c|}{$\begin{array}{c}\text { \%infestation } \\
\text { in brood cells }\end{array}$} & \multirow{2}{*}{$\begin{array}{c}\text { Reduction } \\
\%\end{array}$} & \multicolumn{2}{|c|}{$\begin{array}{c}\text { \%infestation } \\
\text { in adult bees }\end{array}$} & $\begin{array}{c}\text { Reduction } \\
\%\end{array}$ & \multirow{2}{*}{$\begin{array}{c}\text { Grand } \\
\text { mean \% }\end{array}$} \\
\cline { 2 - 3 } \cline { 5 - 6 } & before & after & & before & after & & \\
\hline $\begin{array}{c}\text { Clove oil } \\
\text { (Eugenol) }\end{array}$ & 15.33 & 8.00 & 60.00 & 8.00 & 2.00 & 82.40 & 71.20 \\
\hline $\begin{array}{c}\text { Menthol oil } \\
\text { (Menthone) }\end{array}$ & 15.30 & 8.33 & 58.30 & 12.33 & 5.33 & 69.70 & 64.00 \\
\hline $\begin{array}{c}\text { Camphor oil } \\
\text { (Cineol) }\end{array}$ & 16.00 & 8.00 & 61.70 & 12.33 & 4.33 & 75.40 & 68.55 \\
\hline Untreated & 15.33 & 20.00 & - & 13.33 & 19.00 & - & - \\
\hline
\end{tabular}

Table (3): Mean umbers of fallen Varroa mites after the treatments during December 2015.

\begin{tabular}{|c|c|c|c|c|c|c|c|c|c|}
\hline \multirow{2}{*}{ Treatments } & \multicolumn{7}{|c|}{ Mean number of fallen varroa mites after treatment } & \multirow{2}{*}{ Total } & \multirow{2}{*}{ Mean } \\
\cline { 2 - 9 } & 1 & 2 & 3 & 7 & 14 & 21 & 28 & & \\
\hline $\begin{array}{c}\text { Clove oil } \\
\text { Eugenol }\end{array}$ & 53.67 & 67.67 & 51.67 & 60.00 & 35.00 & 23.33 & 7.33 & 298.67 & 42.67 \\
\hline $\begin{array}{c}\text { Menthol oil } \\
\text { (Menthone) }\end{array}$ & 29.67 & 29.33 & 26.33 & 37.33 & 36.00 & 21.33 & 7.33 & 187.32 & 26.76 \\
\hline $\begin{array}{c}\text { Camphor } \\
\text { oil (Cineol) }\end{array}$ & 46.00 & 48.66 & 51.33 & 53.33 & 62.00 & 18.67 & 13.33 & 293.32 & 41.90 \\
\hline Untreated & 7.67 & 8.00 & 7.33 & 8.66 & 11.66 & 11.66 & 11.00 & 65.98 & 9.43 \\
\hline
\end{tabular}

L.S.D for treatments at $5 \%=0.799$ at $1 \%=1.542$

L.S.D for Days at $5 \%=.0514$ at $1 \%=0.831$

L.S.D for Interaction at $5 \%=0.917$ at $1 \%=1.350$

Table (4): Mean reduction percentages of Varroa mites on brood and adult honeybee colonies treated with certain natural substances during December 2015.

\begin{tabular}{|c|c|c|c|c|c|c|c|}
\hline \multirow{2}{*}{ Treatments } & \multicolumn{2}{|c|}{$\begin{array}{c}\text { \%infestation } \\
\text { In brood cells. }\end{array}$} & \multirow{2}{*}{$\begin{array}{c}\% \\
\text { Reduction }\end{array}$} & \multicolumn{2}{|c|}{$\begin{array}{c}\text { \%infestation } \\
\text { In adult bees }\end{array}$} & $\begin{array}{c}\% \\
\text { Reduction }\end{array}$ & \multirow{2}{*}{$\begin{array}{c}\text { Grand } \\
\text { mean\% }\end{array}$} \\
\cline { 2 - 6 } & before & after & & before & after & & \\
\hline $\begin{array}{c}\text { Clove oil } \\
\text { Eugenol }\end{array}$ & 15.33 & 6.67 & 68.20 & 16.66 & 6.66 & 65.50 & 66.85 \\
\hline $\begin{array}{c}\text { Menthol oil } \\
\text { (Menthone) }\end{array}$ & 16.33 & 8.66 & 61.20 & 14.67 & 9.33 & 45.10 & 53.15 \\
\hline $\begin{array}{c}\text { Camphor } \\
\text { oil(Cineol) }\end{array}$ & 15.00 & 7.00 & 65.90 & 16.00 & 8.00 & 56.80 & 61.35 \\
\hline Untreated & 12.67 & 17.33 & - & 14.67 & 17.00 & - & - \\
\hline
\end{tabular}




\section{REFERENCES}

Abou El-Enain, H.T., A.A. Gomaa and Amany S.M. Abou Lila (2005). Biocidal effect of certain botanical extracts against Varroa destructor in habiting the Egyptian apiaries. J. Agric. Sci. Mansoura Univ., 30 (9): 5617 - 5625

Abou El-Enain, H.T., M.A. Ali and A.A. Eissa (2007). Evaluation of some natural substances for controlling Varroa destructor and their effects on individual activity of honeybee colonies. J. Agric. Sci. Mansoura Univ., 32 (2):1443-1450 .

Abou El-Enain, H.T., Naglaa E. Ghazala and A. A. Taha (2014). Effect of some natural substances for controlling Varroa destructor and honeybee colonies activity - Minufiya J. Agric. Res. Vol. 39 No. 3(2):1131-1137.

Bounias, M., J.F. Andre, M. Nectoux and D.S. Popeskovic (1994). Varroa jacobsoni control by feeding honey bees with organic cupric salts. Bee Science. 3: 3, 111-119.

Calderone, N. W. and M. A. Spivak (1995). Plant extracts used for control of the parasitic mite, Varroa jacobsoni(Acari: Varroidae) in colonies of the western honey bee (Hymenoptera :Apidae). Journal of economic Entomology,88: 11211-1215.

Calderone, N. W., W. T. Wilson and M. A. Spivak (1997). Plant extracts used for control of the parasitic mites Varroa jacobsoni (Acari: Varroidae) and Acaris wood (Acari: Tarsonomidae) in colonies of Apis mellifera (Hymenoptera: Apidae). Journal of Economic Entomology, 90: 1080-1086.

Chen PaoLiang, and Shih Chainlng T. (1995). Population density, infestation rate and distribution of Varroa jacobsoni Oud. in Apis mellifera L. colony. Chinese Journal of Entomology. 15: 4, 305-319.

Colin, M. E. (1990). Essential oils of labiates for controlling honey bee varroasis. Journal of Economic Entomology,110: 19-25.
CoStat version 6.400 Copyright (c) 19982008 . Cohort Software. 798 Lighthouse Ave. PMB 320 , Monterey, CA, 93940, USA.

Dehibes, S.R., M.J. Mendez and O.G. Colina (1992). Varroa found in mexico.Am.bee j., 132(11);728-729.

Elzen, P. J., G. W. Elzen and R. D. Stipanovic (2001). Biological activity of grapefruit leaf burning residue extract and isolated compounds on Varroa jacobsoni. American Bee Journal. 141: 5, 369-371.

Emara, M.M. and Soheir A.M. Elsisi (1994). Formulation and evaluation certain local natural products against varroa mites infesting colonies. J. Agric. Sci., Mansoura Univ., 19(5): 1843-1850.

Gonzalez-Gomez, R., G. Otero-Colina, J. A. Villanueva-Jimenez, J. A. Perez-Amaro and R. M. Soto-Hernandez (2006). Azadirachta indica toxicity and repellence of Varroa destructor (Acari: Varroidae). Agrociencia (Montecillo). 40: 6, 741-751.

Hagigation, F. (2000). Study of Artemisia annual and Sambucus lyulus extracts efficiencies on controlling varroa mite. Proceeding of $4^{\text {th }}$ Iranian Res. Seminar on honey bees.

Henderson, C.F. and E. W. Tilton (1955). Tests with acaricides against the brow wheat mite, J. Econ. Entomol. 48:157161.

Imdorf, A., S. Bogdanov, V. Kilchenmann and C. Maquelin (1995). Apilife VAR: a new varroacide with thymol as the main ingredient. Bee world 76:77-83.

Imdorf, A., S. Bogdanov, R. I. Ochoa and N. W. Calderone (1999). Use of the essential oils for the control of Varroa jacobsoni oud. In honeybee colonies. Apidologie 30:209-228.

Ismail, A. (1953). The English text of Egyptian Pharma copoeia, Cairo University Fouad 1 University press 1953 pg 96, $97,100-101$ and 102- 103.

Jacobson, M. (1983). Control of stored product insects with phytochemicals.In Proceedings $3^{\text {rd }}$ International working 
conference on stored product. Entomology . P. 183-195. Manhattan, U. S. A.

Jimenez, A., R. Mata, R. Pereda, J. Calderon, M.B. Isman, R. Nicol and J. T. Arnason (1997). Insecticidal Limonoids from Swietenia humilis and Cedrela salvadorensis. Journal of Chemical Entomology 23: 1225-1234.

Komeili, A.B. (1988). The impact of the Varroa mite on Iranian commercial beekeeping. Amer. Bee J., 128:423-424.

Kraus, B. and S. Berg (1994). Effect of lactic acid treatment during winter in temperate climate upon Varroa jacobsoni Oud. and the bee (Apis mellifera ) colony. Experimental and Applied Acarology, 18: 454-468.

Liu, T. P. and M. Nasr (1993). Effect of formic acid treatment on the bee, Apis mellifera. Amer. Bee J., 132: 666-668..

Mattila, H.R. and G.W. Otis (2000). The efficacy of Apiguard against varroa and tracheal mites, and its effect on honey production; 1999 trial. Amer. Bee J., 140:969-973.

Mikolojczak, K. L. and D. K. Reed (1987). Extractives of seeds of the Meliaceae: effects on Spodoptera frugiperda (SE.smitly Aca dymma Vittatum F.) and Artemia Salina. Journal of Chemical Ecology 13: 99-111.

Milani, N. (1999). The resistance of Varroa jacobsoni Oud to acaricides. Apidology 30: $229-234$.
Omar, S., M. Macotte, P. Fields, P. E. Sanchez, L. Poveda, R. Mata, A. Jimenez, T. Durst, J. Zhang, S. Mockinnon, D. Leaman, J.T. Arnason and B.R. Philogene (2007). Antifeedant activities of terpenoids isolated from tropical Rutales. Journal of Stored Products Research, 43: 92-96.

Ritter, W. (1981). Varroa disease of the honeybee Apis mellifera. Bee world, 62(4): 141-153.

Shaddel-Telli, A. A., N. Maheri-sisi, A. Aghajanzadeh-Golshani, A. asad-Dizaji, H. Cheragi and A. Mousavi (2008). Using medicinal plants for controlling varroa mites in honey bee colonies. Journal of Animal Veterinary Advances, 7: 328-330.

Wallner, N. (1995). The use of varroacides and their influence on the quality of bee products. Amer. Bee J., 135:817-821.

Wallner, N. (1999). Varroacides and their residues in bee products. Apidologie, 30: 235-248.

Wienands, A. and G. Madel (1988). Haemocytes of honeybee Apis mellifera and their changes during Varroa disease. Entomol. Gener., 14(2):81-92.

Xie, Y. S., P. G. Fields and M. B. Isman (1995). Repellency and toxicity of azadirachtin and neem concentrates to three stored product beetles. Journal of Economic Entomology, 88: 1024-1031. 


\section{دراسة تقييم فاعلية بعض المركبات الاساسية لبعض الزيوت الطبيعية فى مكافحة حلم} الفاروا الذى يصيب طوائف نحل العسل

حمدى طاهر أبو العينين(1) ، أسماء أنور عيسى(1) ، نجلاء الاحمدى غزالة(1) ، سوزلان ابراهيم (2)

(1) قسم بحوث النحل - معهد بحوث وقاية النباتات - مركز البحوث الزراعية

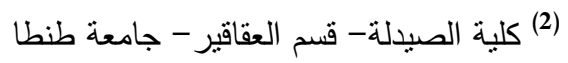

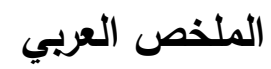

أجرى هذا البحث فى منحل محطة البحوث الزراعية بالجميزة محافظة الغربية وبكلية الصيدلة جامعة طنطا

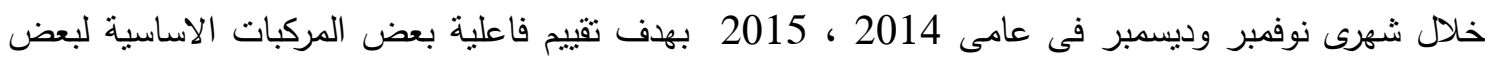

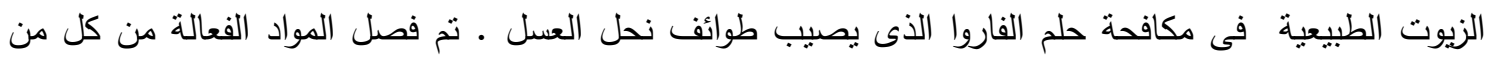
زيت القرنفل - زيت الكافور - زيت النعناع وهى ايكنول - سينول - منثون على التوالى بواسطة التقطير الجزئى . و لقد اوضحت النتائج ان متوسط نسبة الخفض فى الاصابة كانت 71,20 ، 68,55 و 64,00 \% على التى التوالى

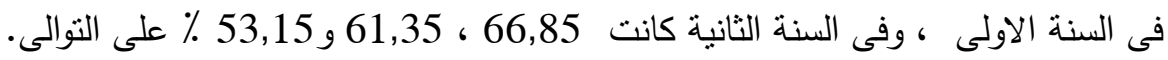
توصى النتائج بإستخدام المادة الفعالة من كلا من زيت القرنفل (ايكنول)، زيت الكافور (سينول ) وزيت النعناع

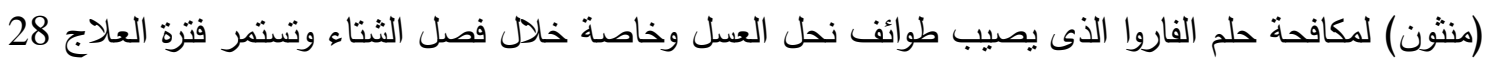
يوم مع مراعاة عدم زيادة درجة الحرارة عن 27 م حتى لا تئثر على انشطة طوائف نحل العسل. 